\title{
DESIGN AND BUILT AN EXPERT SYSTEM APPLICATION FIR DIAGNOSING HUMAN EYE DISEASES BY USING FORWARD CAHINING METODH WEB-BASED
}

\author{
Harkamsyah Andrianof \\ Universitas Putra Indonesia YPTK Padang \\ E-Mail : harkamsyah.andrianof@upiyptk.ac.id
}

\begin{abstract}
Abstrak
The eye is one of the five senses that has a very important role in human life, namely as the organ of vision. If there is interference with the eye or there is a disease, it is very influential on human vision. Its mean that we can conclude that eye is very important in our lie and must be keep for our body. The purpose of this research to planning and develop the diagnose of expert system about diagnosing of diseases in the eye which include disease information about symptoms or the solution and have role to replace and imitate the process of the reason from an expert in solve the specification problem. the method used for reasoning is forward chaining method. The result of this research is expert system of diagnosing eyes diseases in humans which computerized who can be used for giving information and have benefit in diagnosing disease.
\end{abstract}

Key Word: Forward, Chaining, Eye, Disease, Expert, system, PHP dan MySQL

\section{INTRODUCTION}

The eyes are the sense that are needed in the vision process. If there is has damage in the eyes, it will result something very bad, that is not being able to see and to do something in human life. It's means that, we must keep the eyes health to launch our daily activities.

With the development of technology that is very fast, in the field of medicine at this time also has been use technology to help improve better service to wide community. Doctor has the very busy job, so that he needs expert system to diagnose many of disease such as heart, kidney, stroke, cancer, teeth, skin and eye.

Expert system is one part of artificial intelligent which has knowledge and experience that is entered by one or many experts into certain area knowledge so that everyone can use it to solving the various specific problem. In this case to be solve is a diagnose of eye disease in humans.
In this case, the writer takes the title "DESIGN AND DEVELOPMENT OF HUMAN EYE DISEASE DIAGNOSIS SYSTEM APPLICATIONS USING WEB-BASED FORWARD CHAINING METHOD"

The author raised the title above due to several factors namely, how the expert system works on diagnosing human eyes and solution to overcome the eye diseases. So can get the faster and more efficient result in using this method.

\section{LITERATURE REVIEW}

Expert system is an information system that contains about expert knowledge so that it can be used for consultation. The knowledge of an expert owns by an expert system can be used to answer the difficult question (consultation). This system began to developed in the middle 160s, and develop by Neel and Simon. 
The benefits and disadvantages of expert system

It so many capabilities and benefits provided by expert system so that it becomes popular, according to (T. Sutojo. Dkk, 2011):

1. Increase the productivity because it's come faster

2. Make a layman work as an expert

3. Improve the quality by giving consistent revise and reducing error

4. Able to capture one knowledge and expertise

Beside the benefits, there are some disadvantages in the expert system, including (T. Sutojo. Dkk, 2011):

1. The cost is very expensive to make and maintain it

2. It's difficult to develop due to limited expertise and available of expert

3. Expert system is not $100 \%$ is true

Structure of expert system

There are two important parts in expert system, they are development environment and consultation environment

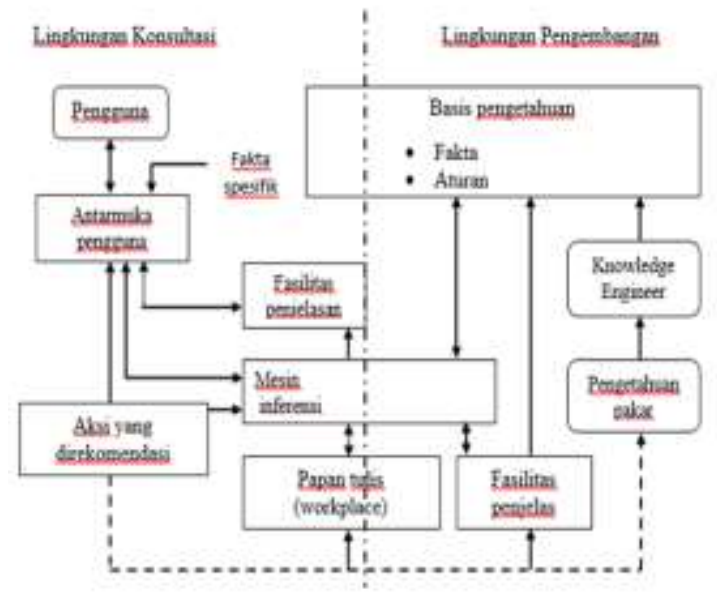

Sumber : (T.Sutojo.dkk, 2011)

Picture 2.1.2 Structure of expert system

2.2 Forward Chaining
Forward chaining is a front tracking which start from collection of fact who find the match hypothesis to get the best conclusion.

Sometimes call data-driven, because inference engine using information specified by user to move to the entire network from logic "AND" and "OR" until in a terminal as object. If inference engine can't determine the object, so I will ask to other information.

\section{Forward Chaining method}

Forward chaining method is a find or technique front tracking method who began by ready information and merging of rule to produce a conclusion or aim. Forward chaining using data orientation approach. Computer will analyses the problem which find the match fact in IF part from IF-THEN. The following basic rule f forward chaining. Tautik. A (2009).

\section{ANALYSIS AND DESIGN}

Analysis of the problem

The analysis of the problem who conducted by the researcher at this time, has a relationship with eye disease suffer by society in general. Analysis of the problem do to find the solution and countermeasures.

Data collection and information

From the result of data collection and information which is obtain by researcher to the expert, so researcher can develop to the eyes healthy solution.

Table of types of eyes disease Here are some types of eye disease.

\begin{tabular}{cc}
\hline Code & Types of eye disease \\
\hline P01 & Conjunctivitis \\
\hline P02 & Cataracts \\
\hline P03 & Glaucoma \\
\hline P04 & Presbyopia \\
\hline
\end{tabular}




\begin{tabular}{cc}
\hline P05 & Retinal detachment \\
\hline P06 & Chuckle \\
\hline P07 & Mild irritation \\
\hline P08 & Graves disease \\
\hline P09 & Neuritis Optic \\
\hline
\end{tabular}

Symptom data

There are some symptoms from eye disease.

\begin{tabular}{ccl}
\hline No & Kode & \multicolumn{1}{c}{ SYMPTOMS } \\
\hline 1 & G1 & Red eye \\
\hline 2 & G2 & Sticky in the morning \\
\hline 3 & G3 & Hot eyes \\
\hline 4 & G4 & Feels paint full \\
\hline 5 & G5 & Run away \\
\hline 6 & G6 & Headache \\
\hline 7 & G7 & Itchy eyes \\
\hline 8 & G8 & Can't stand the light \\
\hline 9 & G9 & Dilate pupils \\
\hline 10 & G10 & Visible flash of light \\
\hline 11 & G11 & Watery eyes \\
\hline 12 & G12 & Nausea \\
\hline 13 & G13 & Difficult to see the light \\
\hline 14 & G14 & Vision lost on one eye \\
\hline 15 & G15 & Swollen eyes \\
\hline 16 & G16 & Tied eye \\
\hline 17 & G17 & $\begin{array}{l}\text { Severe pain in the back of } \\
\text { the eye }\end{array}$ \\
\hline 18 & G18 & Shortsightedness \\
\hline 19 & G19 & Quick blink response \\
\hline 20 & G20 & Double up eye \\
\hline & &
\end{tabular}

Data Solution

Each disease has a way of handling or a solution of the type of eye disease that exists, the following ways to treat early eye disease

\begin{tabular}{|c|c|c|}
\hline 1 & Conjunctivitis & $\begin{array}{l}\text { Hand and face } \\
\text { hygiene is very } \\
\text { important. Never } \\
\text { use towels } \\
\text { together, } \\
\text { especially if there } \\
\text { are other family } \\
\text { members affected } \\
\text { by conjunctivitis. }\end{array}$ \\
\hline 2 & Cataract & $\begin{array}{l}\text { Brighter glasses } \\
\text { and lights might } \\
\text { help mild } \\
\text { cataracts. The } \\
\text { most effective } \\
\text { step is surgery. }\end{array}$ \\
\hline 3 & Glaucoma & $\begin{array}{l}\text { Glaucoma can be } \\
\text { treated with eye } \\
\text { drops, drugs } \\
\text { taken, laser } \\
\text { treatment, or } \\
\text { surgical } \\
\text { procedures. }\end{array}$ \\
\hline 4 & Presbyopia & $\begin{array}{l}\text { Glasses, the use } \\
\text { of glasses is a } \\
\text { simple and safe } \\
\text { way to handle } \\
\text { presbyopia. }\end{array}$ \\
\hline 5 & $\begin{array}{c}\text { Retinal } \\
\text { detachment }\end{array}$ & $\begin{array}{l}\text { Diabetics should } \\
\text { control their } \\
\text { blood sugar } \\
\text { levels carefully. }\end{array}$ \\
\hline 6 & Chuckle & $\begin{array}{l}\text { To deal with } \\
\text { chains, especially } \\
\text { in children } \\
\text { usually avoid } \\
\text { direct contact } \\
\text { with dusty } \\
\text { environments. }\end{array}$ \\
\hline 7 & $\begin{array}{l}\text { Mild } \\
\text { irritation }\end{array}$ & $\begin{array}{l}\text { Wash your hands } \\
\text { often because } \\
\text { indirectly during } \\
\text { the day you can } \\
\text { touch your eyes } \\
\text { approximately } 10 \\
\text { times } \\
\text { unconsciously in } \\
\text { all conditions. }\end{array}$ \\
\hline
\end{tabular}




\begin{tabular}{|c|c|c|}
\hline 8 & Raves disease & $\begin{array}{l}\text { Eat various types } \\
\text { of foods that } \\
\text { contain lots of } \\
\text { nutrients such as } \\
\text { vitamins and } \\
\text { minerals on a } \\
\text { regular basis. }\end{array}$ \\
\hline 9 & $\begin{array}{l}\text { Neuritis } \\
\text { Optik }\end{array}$ & $\begin{array}{l}\text { Treatment for } \\
\text { optic neuritis can } \\
\text { be done with } \\
\text { medication but } \\
\text { usually the vision } \\
\text { will return in less } \\
\text { than } 12 \text { months. }\end{array}$ \\
\hline
\end{tabular}

Functional requirements analysis Functional requirements analysis describes the process of activities that will be applied in the system and explains the needs needed for the system to run well and in accordance with needs

System Design with Use Case Diagrams Use case diagrams illustrate the processes carried out by actors on a system. As for who acts as an actor in this expert system are the admin and user.

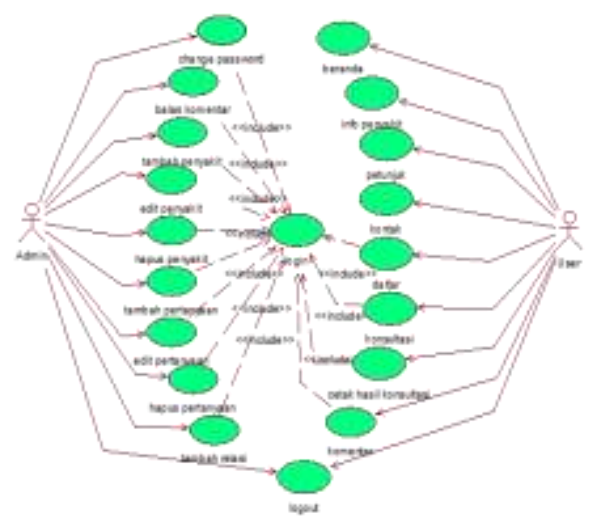

Figure 1. System Design with Use Case Diagrams

\section{RESULTS AND DISCUSSION}

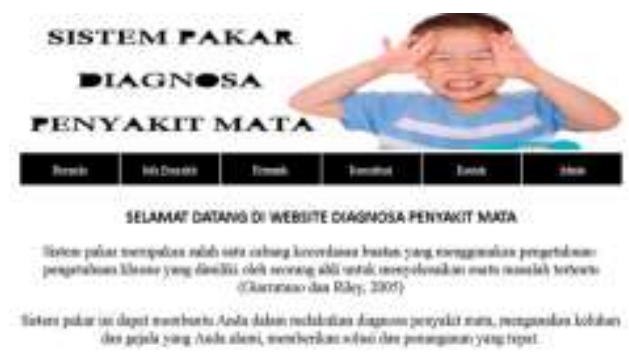

Figure 2. diagnoses eye disease

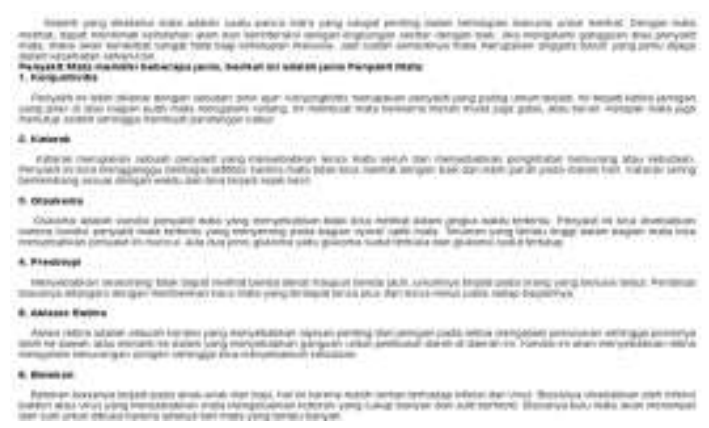

Figure 3. Eye disease information view

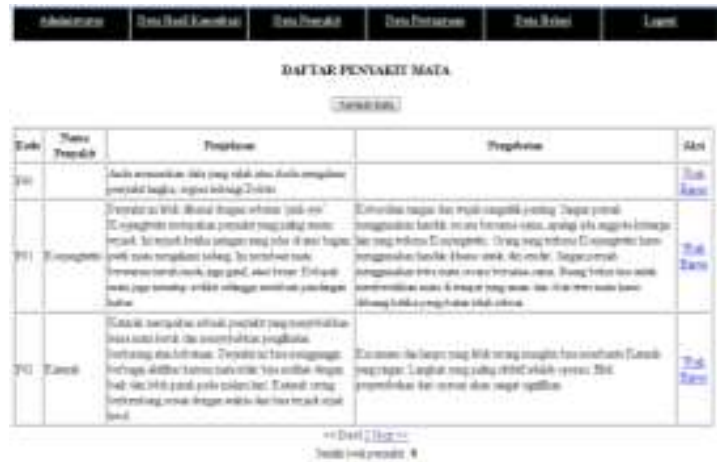

Figure 4. kinds of eye disease

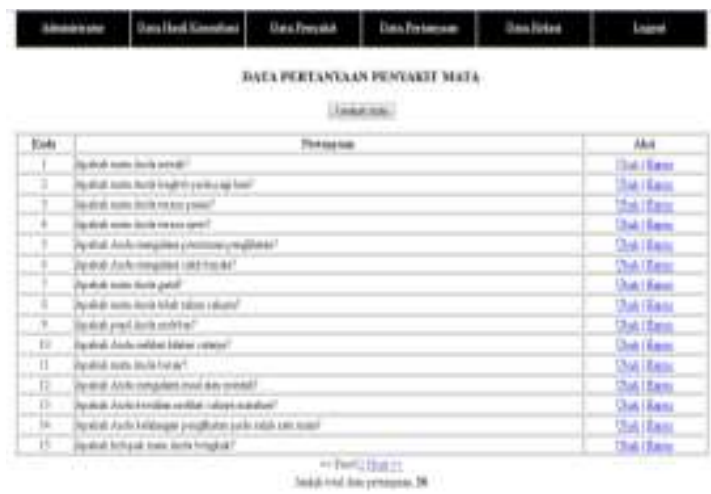

Figure 5. Question data view 


\section{CONCLUSION}

From the description of the existing problems, and based on the chapter's analysis, the conclusions can be drawn as follows:

1) The design of an expert system for diagnosing eye diseases is able to trace the symptoms of the disease and the provide solutions based on the tracing of the answers to the questions given by a system, so that users can recognize the symptoms, diseases and solutions that they suffer.

2) This expert system can find out and provide information on eye diseases whether included in the category of the disease experienced contained in the system.

3) This Forward Chaining method can determine the results of the analysis almost at the same level as an expert or expert doctor in the field of eye disease.

\section{REFERENCES}

[1] J. Nugroho et al., "Artificial Intelligence," Fac. MIPA Univ. Negeri Makassar, 2018.

[2] P. W. Achmad, I. -, and K. A. Saputro, "SEMIOTIC STUDY OF MASCULINITY IN PHOTOGRAPHY OF SALT CIGARETTE ADVERTISING OF DJAJA SALT EDITION“ SECRET OF DJAJA '2015," J. Photogr. Arts, Media, 2017, doi: 10.24821 / specta.v1i2.1906.

[3] AN Fajero, H. Haryanto, T. Sutojo, and E. Mulyanto, "Fuzzy Logic for Dynamic Behavior in Crafting Systems in Arithmetic Learning Games," J. Eksplora Inform., 2020, doi: 10.30864 / Explora.v9i2. 367.

[4] T. U. Azmi, H. Haryanto, and T. Sutojo, "Prediction of the Amount of Jenang Production in PT Menara Jenang Kudus Using Fuzzy Tsukamoto Logic Method," SISFOTENIKA, 2018, doi: 10.30700 / jst. v8i1.176.
[5] Hamdani, "Expert System for Diagnosing Eye Diseases in Humans," J. Inform. Mulawarman, 2010.

[6] A. H. Aji, M. T. Furqon, and A. W. Widodo, "Expert System for Diagnosing Pregnant Women using the Certainty Factor (CF) Method," J. Pengemb. Teknol. Inf. and Computational Sciences., 2018.

[7] P. A. Saputro and C. Supriyanto, "Analysis of Forward Chaining Methods in Expert Systems in Diagnosing Diseases in Cattle," Res. J. Pharm. Technol., 2012

[8] Pramesti, A. A., Arifudin, R., \& Sugiharti, E. (2016). Expert System for Determination of Type Lenses Glasses using Forward Chaining Method. Scientific Journal of Informatics, 3(2), 177-188.

[9] Sihotang, H. T., Riandari, F., Simanjorang, R. M., Simangunsong, A., \& Hasugian, P. S. (2019, July). Expert System for Diagnosis Chicken Disease using Bayes Theorem. In Journal of Physics: Conference Series (Vol. 1230, No. 1, p. 012066). IOP Publishing.

[10] Huang, M. J., \& Chen, M. Y. (2007). Integrated design of the intelligent webbased Chinese Medical Diagnostic System (CMDS)-Systematic development for digestive health. Expert Systems with Applications, 32(2), 658-673. 